\title{
Does Leadership Style Matter for Enhancing Economic Performance?
}

\author{
Krishnahari Budhathoki ${ }^{1}$
}

\begin{abstract}
This paper is an analysis of determinants of political leadership on economic performance. It reviews the theoretical and empirical literature on the roles of political leadership in economic growth. It adds to theliterature on understanding of the impact of political leadership styles on economic advancement of a country, and suggests future directions for research in this area. Through qualitative method of inquiring on review of literature, the paper analyses the role of national political leadership style in theoretical basis of Goleman six leadership styles on the economicperformance of a country like coaching, authoritative, affiliative, democratic, pacesetting, and coercive styles of leadership. This study primarily focuses on the leadership styles of the founding leader of Singapore, Lee Kuan Yew $(L K Y)$ and his economic performanceon Singapore's economy. Considering the history of great personalitiesin the world as true leaders, who have constructively changedthe history of their nations, leadership style plays important role informulating and implementing of economic policies and actions. The study shows that LKY embraces all leadership styles in different scope and heights to get positive economic performance and to avoid constraints of economic environment.
\end{abstract}

Keywords: Political leadership styles, Economic performance, Goleman, Lee Kuan Yew, Singapore.

\section{Introduction}

Leaders and leadership are pervasive in formal and informal organization. Leaders are central to social and economic movements, yet scholars have devoted relatively little attention to understanding the concept of leadership or its effects on different socio-cultural and economic political movements. Leaders play a critical role in collective action, shaping movements in numerous ways. They define goals and advance strategies. They mobilize followers, galvanize different aspirations of people, and forge coalitions. Leader's action, rhetoric, and style affect economic outcomes.Political leadership is broader concept and field. A political leader is expected to meet the collective needs of society and paint a vision for the future; and to build a strong economy and manage public funds. The demands and

1 Mr. Budhathoki is a Ph. D. scholar at Central Department of Economics, Tribhuvan University, Nepal. Email: kbhpeculiar@gmail.com 
expectations placed on political leaders frequently exceed those for leaders in any other domain of society. Political leaders continuously move in a cycle of problem solving and motivation, and endeavor to pull the support and participation of citizens into that energy.

Some empirical results suggest that the effects of individual leaders are countable and constraints on a leader's power are to be managed through different competencies. Leaders affect policy outcomes. Scholar claim individual leaders can play crucial roles in shaping the growth of nations. Literature on political leadership state that strong leaders at critical times had brought their countries together with a common vision. Jefferson, for instance, had a broad vision of the United States' spanning the continent and trading with China; Lincoln's vision maintained national unity in the face of tremendous calamity and conflict; and Garibaldi united Italy, enabling it to compete more effectively against neighboring states.

Economic development is the expansion of capacities that contribute to the advancement of society through the realization of individual, firm and community potential. Economic Development is measured by a sustained increase in prosperity and quality of life through innovation, lowered transaction costs, and the utilization of capabilities towards the responsible production and diffusion of goods and services.

This study is based on assumption that political leadership is a key in enhancing economic development of a nation. Effective roles and responsibilities of political leadership are crucial in economic growth. Political leadership formulates economic policies and builds the nation by implementing stated policies. A leader is a person who is elected or appointed or who has emerged from the group to direct and coordinate the group members efforts toward some given goal. A leader marshals and challenges people to transform a vision into a reality. A leader is one or more people who selects, equips, trains, and influences one or more followers to achieve stated mission and objectives (Fiedler \& Garcia, 1987).

Among research, leadership was one of the most observed and yet least understood phenomenon on earth. The study of leadership remains conflicted because the existing construction of knowledge seems to be still explored.The point is to find what leadership elements and which policy choices are important and determinants for enhancing economic goals of a country. Similarly, the important point of study is that how leaders' economic role are shaped and how leaders create economic environment to speed up development are important. It is because politics and economics are highly interwoven and interdependent. Political leaderships have widespread impact on economic and social life in a country. So their effective roles should be discussed for betterment of lives of people around the world.

\section{Review of Literature}

Political leader is not only a politician and political leadership is neither only personality, nor only power, but it is a kind of process. The main condition of political leadership is an ability and possibility to influence people, so that people would follow leader willfully. Political leaders distribute responsibility, empower people and aid deliberations. They also know how to construct or reconstruct situation that require public attention. Mainly, leader 
uses power, payment and persuasion for completion of stated vision on. All three of these choices are options for leaders, but the one that is most sustainable and has the most enduring positive impact on an individual's leadership is persuasion.

Bass (1990) claims that effective leaders in business build organizations that withstand uncertainty, change, and competition. The sustained impact of leaders on business success can further be realized through examining leadership styles and the types of individuals operating the businesses. Leaders lead themselves and others using leadership styles based on personal experience, background, education, or training. Different styles of leadership impact the level of performance and performance improvement within an organization. Again, Bass (1985) posited that the transactional leader is most efficient when the leader develops a mutually reinforcing environment that facilitates exchange between the leader and the followers, predicated on contingent reward and management by exception.

Bertrand and Schoar (2003) suggest that individuals themselves can shape outcomes. They demonstrate that CEO (leader) fixed effects are correlated with firms profitability. Their study is important because it suggests that leader plays important roles in bringing outcomes. However, as the authors explain, it is not clear why this happens and why some leaders do succeed in economic enhancement of a country while others fail?

Jones and Olken (2005) empirically claim that leader impacts growth. They are the renowned scholars on having empirical study of political leadership effects in economics. They examined the case of national leaders. By using, as a natural experiment, 57 parliamentarians deaths, and economic growth data on many countries between the years 1945 and 2000, the authors trace linkages between national leaders and national growth rates. The authors reject the deterministic view where leaders are incidental. They claimed that political leadership matters economic growth through policy intervention.

Hermalin (2007) has offered theoretical explanations of leadership who focuses on the incentives used by leaders to induce followers to follow. High economic growth is often seen as evidence of good national leadership. Leaders who presided over periods of high growth - like Deng Xiaoping in China, Lee Kuan Yew in Singapore, Park Chung Hee in South Korea, and more recently, Paul Kagame in Rwanda - are often given credit for these 'Growth Miracles'.

Brady and Spence (2010) study on leadership and growth within 13 high growth countries and publish report on World Bank Commission on Growth and Development in year 2010. The report singles out 13 economies that have achieved high growth over 25 years or more and suggests that "Making the right choices over this set of components is what leaders in the high-growth economies have done" An earlier report in 2008 by the same commission finds that "Successful cases share a further characteristic: an increasingly capable, credible, and committed government. Growth at such a quick pace, over such a long period, requires strong political leadership". They expose about the role individual national 'leaders' plays noting that they are particularly responsible for "Making the right choices" in early stages of development, and then adjusting strategies and choices in response to changing circumstances. But they ignore what leadership qualities and styles impacts positive. 
58 | The Economic Journal of Nepal (Issue No. 151)

Wolinski (2010) mentions about various leadership theories like - Trait Theory, Skills Theory, Situational Theory, Contingency Theory, Path-goal Theory, Transformational Theory, Transactional Theory, and Servant Leadership Theory.

Besley, Montalvo and Reynal-Querol (2011) claim that educated leaders matter more. Using data on more than one thousand political leaders between 1875 and 2004 to investigate whether has more educated leaders affect economic growth rates. They exploit an expand set of random leadership transitions due to natural death or terminal illness and first show that the individual characteristics of leaders matter for growth. Then, they provide evidence supporting the view that heterogeneity among leaders. Educational attainment is important and that growth is enhanced by having leaders who are more highly educated

Kebonang and Kebonang (2013) state that it is made tradition that historical, institutional and structural factors explain the causes of under-development in many countries, they argue that equally at the core of under-development is poor political leadership. They argue that socio-economic challenges can be over-come by a leadership that places national interests above personal ones.

North House (2013) defines leadership as a process whereby an individual influences a group of individuals to achieve a common goal. Leaders motivate their followers to do more than the followers originally intended and thought possible. The leader sets challenging expectations and achieve higher standards of performance. Leaders and leadership are not synonymous, but are analogous to one another. While leaders are expected to lead and influence their subordinates, leadership is a process of influencing people towards achieving a clear goal.

Zhang (2015) uses data on more than 1000 national leaders between 1875 and 2005 to examine how individual characteristics influence the rate of economic growth. The study claims that leadership characteristics affect relevant policy outcomes and then economic growth.

Ekene and Ugwunwanyi (2016) state that the ability of a person to effectively and efficiently harness as well as influence the material and human resources of a country is very fundamental to the development of an organization. It is obvious that leadership plays a very vital role in societies especially in the areas of managing the material and non-material resources. Leadership is seen as the way a person or group of persons influence the skills, efforts and knowledge of other people towards achieving a goal or set of goal.

Over the years, different leadership styles and models have emerged in various disciplines, some literature are reviewed as following;

Blondel (1987) claims that leadership is essentially a phenomenon of power; it consists of the ability of the one or few who are at the top to make others do a number of things. And more specifically the national political leadership is the power exercised by one or a few individuals to direct members of the nation towards action. 
Goleman(2000) basically proposes six styles ofleadership namely Coercive, Authoritative, Affiliative, Democratic, Pacesetting and Coaching. Coercive style of leadership demands immediate compliance and has overall negative impact on climate in organization. It works better in time of crisis or in case of problems with workers. Authoritative mobilizes people toward vision, works especially better, if new vision or new direction is required. Affiliative concentrates on harmony and builds emotional bonds, works good, when people face difficult circumstances. Democratic forges consensus through participation and works successfully, if there is a need to build buy-in or in consensus, or to get input from valuable team members. Pacesetting style sets high standards for performance, works effectively with motivated and competent people, knowing, how to get quick results from them. Coaching develop people for future, works especially good if there is a need to help others improving performance or setting long term strengths. Goleman further believed that leaders' singular job is to get results. Realizing these results depends on several factors and leadership style is one of these factors. Choosing the right style for the situation is matter of great importance.

Barker (2001) shows how well-balanced leadership styles and strategies impacts positive change and effectiveness in the organizations. Based on field research at a number of comprehensive schools, this paper explores how secondary head teachers contribute to the effectiveness of their schools. Evidence about leadership is used to compare and contrast successful and less successful head teachers. Despite the complications of social context, internal politics and external pressure, strong heads seem to adopt similar, wellbalanced leadership styles and strategies that correlate with well-motivated students and staff. In contrast, poor performers operate a limited range of styles and strategies and elicit a negative response from their colleagues.

Kendra (2012) identifies three leadership styles. They include authoritarian/autocratic leadership, participative/democratic leadership, delegated/Laissez-Faire leadership. In many ways, the coercive and bureaucratic leadership styles are autocratic in nature. Participative leaders encourage group members to participate, but retain the final say over the decision-making process. Group members feel engaged in the process and are more motivated and creative. Participative or democratic leadership style is generally the most effective leadership style because the democratic leader offers guidance and encourages group members to be part of the leadership process. Laissez-Faire leadership offers little or no guidance to group members or followers, and leaves the decisionmaking process up to group members.

Singapore is a developed country in the world. The third world developing country has been transformed in a first world developed country within the single political leadership of Lee Kuan Yew. There are many developing countries having not economically developed and they are still in the same position and developed little more. What were the leadership styles of Lee Kuan yew that contributed to best economic performance in Singapore is to be explored in the study. 
60 | The Economic Journal of Nepal (Issue No. 151)

\section{Objectives of the study}

The general objective of the study is to review major styles of political leadership and theories of leadership. It also established linkage of various styles of political leadership with economic performance and shaping of economic enhancement of a country. There may be many aspects of political leadership and many exemplary countries enhancing pace of economic growth with various dynamics of political leadership contributions. However, the specific objectives of the study are - to explore various style of political leadership in contributing economic performance of a country; to analyze the influence of style of political leaders in economic action and policies; and to assess features of leadership of LKY in connection with positive outcomes of economic performance.

\section{Methodology}

The study used qualitative research method while the research design is descriptive as well as exploratory. The study is mainly basedon secondary data and information related to political leadership, economic performance and shaping of economic enhancement of a country. The major sources of data and information are various books, booklets, journals, articles, research papers and websites. The basic tool of data and information collection is review of literature related to the study.

\section{Lee Kuan Yew (LKY) Styles of Leadership}

LKY served as the first prime minister of Singapore from 1959 to 1990. LKYis recognized as the father of national founding and credited with rapidly transitioning the country from a developingthird world country into a developedfirst world country within a single generation under his leadership (Lee, 2000). LKY forged a system of meritocratic, highly effective and non-corrupt government and civil service to enhance economic growth. Many of his policies are now taught at the 'Lee Kuan Yew School' of public policy. LKY implied meritocracy and multiracialism as governing principles, making English the common language to integrate its immigrant society and to facilitate trade with the West, whilst mandating bilingualism in schools to preserve students' mother tongue and ethnic identity.

LKY recognized that Singapore needed a strong economy in order to survive as an independent country, and launched a program to industrialize Singapore and transform it into a major exporter of finished goods. LKY encouraged foreign investment and secured agreements between labour unions and business management that ensured both labour peace and a rising standard of living for workers. While improving health and social welfare services, LKY continually emphasized the necessity of cooperation, discipline, and austerity on the part of the average Singaporean.

Singapore is a rapid transformed country during the last forty-five years. From an entrecote predominant towards commerce and services in the mid-1960s into an economy which presently specialize in high value manufacturing activities, and regional financial hub for business services in East Asia (Richardson, 1994). The country is also a rapidly 
expanding financial center served by most of the international commercial and merchant banks. Singapore is highly competitive economy.

Since independence of 1959, Singapore's economy has had an experience which was not common among other former colonies such as: sustained economic growth; reliance on foreign corporations; low inflation; high saving rates etc. (Richardson, 1994). GNP of Singapore increased to more than thirteen fold between 1960 and 1999 and also the country witnessed a sharp decline in both the number of people in poverty and in infant mortality. The annual real GDP growth rates averaged around 8 percent between 1965 and 1990. Following table 1 and table 2 speak some more about economic and population situation of Singapore.

Table 1: Singapore's GDP Per Capita Income in the last 60 years.

\begin{tabular}{|c|c|c|c|c|c|c|c|c|}
\hline \multicolumn{7}{|c|}{ GDP per capita Income ( Current \$) } \\
\hline $\mathbf{1 9 6 0}$ & $\mathbf{1 9 7 0}$ & $\mathbf{1 9 8 0}$ & $\mathbf{1 9 9 0}$ & $\mathbf{2 0 0 0}$ & $\mathbf{2 0 1 0}$ & $\mathbf{2 0 1 8}$ & $\begin{array}{c}\text { Total growth \% } \\
\text { since 1960 }\end{array}$ & $\begin{array}{c}\text { Average yearly } \\
\text { growth \% }\end{array}$ \\
\hline 428 & 925 & 4928 & 11861 & 23852 & 47236 & 64581 & 14987 & 254 \\
\hline
\end{tabular}

Source: World Development Indicator, updated on 4/09/2019,From World Bank website (worldbank. org) made necessary calculation by researcher

Table 2: Population and Area of Singapore

\begin{tabular}{|c|c|c|c|c|c|c|c|c|c|}
\hline Population & Yearly & Net & Density & Land & Migrants & Fert. & Med. & Urban & World \\
\hline 2019 & Change & Change & $\left(\mathrm{P} / \mathrm{Km}^{2}\right)$ & $\left(\mathrm{Km}^{2}\right)$ & (net) & Rate & Age & Pop\% & Share \\
\hline $5,840,342$ & $0.79 \%$ & 46,005 & 8,358 & 700 & 27,028 & 1.2 & 42 & N.A. & $0.08 \%$ \\
\hline
\end{tabular}

Source: https:/www.worldometers.info/world-population/population-byuntry/

Leaders passionately believe that they can make a difference. They envision the future, creating an ideal and unique image of what the organization can become, continuously looking for new and better ways to do things. Leaders look for innovative ways to improve nation. Leaders foster collaboration and build spirited teams. They actively involve others. They strengthen others, making each person feel capable and powerful. They actively motivate members to achieve their full potential. These are what LKY applied in his life to get the country prosperous.

\section{Coercive Style of Leadership (Commanding Leader)}

Coercive leaders use an autocratic approach to leadership. This style often depends on orders, the threat of punishment, and tight control. The coercive leadership style is best used in crisis situations, to jump start fast-paced change. Coercive leader has clear perception and requires their employees to do what they are exactly told. Thus, the leader's extreme top-down decision making skills put new ideas on the vine (Goleman, 2000). To establish professionalism and disciplines in bureaucracy, Lee formulated certain laws and norms. For instance, he made compulsory to have employees hair cut short. As in the case of language, he forced people to learn English too.

LKY himself started to learn Mandarin and Malay. LKY sent all his children to Mandarin 
Chinese schools and later to English universities. LKY often spoke that he does not work on a theory. Instead he will make this work. He reviews what alternatives best and chooses a solution which offers a higher probability of success, but if it fails, he has some other way.

As a new independent economy, Singapore didn't have natural resources such as land and human capital much and must have survived and reformed. For this, many economic issues and problems were to be solved. Lee commanded for the prosperous economy of a country to shape the mindset of people to work what lee commanded.

There are many problems and challenges in applying coercive leadership styles. A lot ideological differences and racial strife have made it compulsive to moderately use for betterment of nation, which is what Lee's leadership style has been argued as inapplicable in democracy. Goleman (2000) posited that the coercive style undermines one of the leader's prime tools-motivating people by showing them how their job fits into a grand shared mission. To Goleman, the coercive style is the least effective among all the six styles as applied in most situations.

For economic development, national security within the country and outside must have addressed. So, LKY initiated a Nation Building National Service (military training), which was mandatory for young men to join for two years. This was a successful experiment in developing Singaporean identity among the youngsters of all races who were hitherto concerned with their own interests and not of the interest of the country. More or less LKY seems to be a strict disciplinarian demanding the tasks to be done rather than coaxing the followers to do something. He applied the same principles when dealing with the citizens. Rather than using motivational methods to encourage higher levels of industrial anticipation, for instance he simply passed legislation setting down longer working hours and limiting fringe benefits for Singapore workers and applies mission for rapid economic growth.

\section{Authoritative Style of Leadership (Visionary Leader)}

Authoritative leadership is most effective when nation needs a new vision. Leader using the authoritative leadership style are inspiring, and they move people toward a common goal. Authoritative leaders tell their teams where they're all going, but not how they're going to get there, they leave it up to team members to find their way to the common goal.

Language is important medium of economic actions by which not only research and development can be done, but also economic communication made worldwide. So, as visionary leader, LKY changed language policy. He wanted every Singaporean to be bilingual, fluent in English and one other national language (Mandarin, Malay, and Tamil). English language was designated to be the language of business while other languages were kept as official languages. English language education was promoted as a means to create linkages between races that spoke different languages and also as a means to access western knowledge.

Lee focused on economic prosperity and for this he formulated economic growthfriendly policies as a visionary leader. For economic development, foreign investment should 
have been attracted highly and to attract foreign investment, Security within the country and outside must have been addressed. So, he initiated a Nation Building National Service (military training). Authoritative stylefocus on increasing member's expertise, vision, selfconfidence. He was able to achieve that by making a salary of the government employees as much as private sector employees. This helped to decrease the corruption rate in Singapore drastically.

LKY had a vision of making Singapore the business hub of the world. LKY was able to do that by encouraging MNCs to establish their businesses in Singapore by giving them some benefits including low taxes and a business-friendly environment. The low tax incentive is still applicable in Singapore for foreign investors, which is why it is known as the tax haven.

The authoritative leader makes sure that the mission statement is built into the company's strategic planning process as the designated driver of growth (Goleman, 2000). Therefore, the authoritative leader is visionary, he motivates people by making clear to them how work fit into larger vision for the organization. The authoritative leader also maximizes commitment to the organization's goals and strategy. Goleman (2000) contended that an authoritative leader states the end but generally gives people plenty leverage (leeway) to devise their own means.

LKY was a great visionary who has left behind a legacy of a modern and prosperous Singapore that is the envy of many nations. LKY was regarded as one of the most prominent elder statesmen and influential leaders not only in Asia but globally. LKY was the first and longest serving prime minister of Singapore; and it was his leadership that brought third world Singapore into a thriving metropolitan city in a stunning three decades. He had the strategic insights and leadership skills to move the country forward. Because of him and his team of pioneer generational leaders, Singapore has undoubtedly been a better and more progressive society than it would have been without them.

To provide employment to all citizens was very challenging. Therefore, to address high unemployment, tourism helped but did not completely resolve the unemployment problem. Economic Development Board chairman Hon Sui Sen, and in consultation with Dutch economist Albert Winsemius, LKY set up factories and initially focused on the manufacturing industry. LK Yimplemented population policy to enhance social development too.

\section{Affiliated Style of Leadership}

The affiliated leadership style promotes harmony within the team. This style connects people together, encouraging inclusion and resolving conflict. LKY wanted a unified Singapore where racial strife, cultural and ideological differences was prevalent. He developed and respected Singapore as multi-racial, multi-cultural and multi-religious country. LKY knew that economy could be enhanced through peace and unity of people and also valued all cultures and cultural norms. LKY listened to the opinions of his cabinet ministers when he was sure about the loyalties of those people towards the common Singaporean interest. LKY gave value the emotions of others, and put a high value on their needs and also listened to people and motivate them for building better Singapore. 
This style can be used whenever there is team tension or conflict, when trust has been broken, or if the team needs to be motivated through a stressful time. LKY always knew his limits in oppressing his opponents. LKY never used violent or cruel punishments towards his political opponents. LKY respected the ideas of people and opponents. Leaders who use the affiliated style are highly focused on emotion and learnt how to resolve conflict and how to be optimistic. LKY was always in the vision of making big Singapore. For this, he united people, colleagues and staff with affiliated style of leadership to fill up the sense of unity and economy prosperity of a country.

A leader without passion for his vision can never influence his/her followers for a long period of time. Passion is an ambition that is materialized into action to put as much heart, mind, body, and soul into something as much as possible. Similarly, LKY was a passionate leader who did whatever it took to make things happen. LKY had a huge task upon his shoulders, making Singapore what it is today; consistent and persevered, he wanted nothing but perfection. Once he was asked what he had given to Singapore he replied with pride in his eyes 'My whole life'.

According to Goleman, this style revolves around people-its proponent's value individuals and their emotions more than risk and goals (Goleman, 2000). Usually, the affiliated leaders keep their employees happy, develop team trust, and create harmony among them. The leader gives people the freedom to do their job in the way they think is most effective. LKY used two leadership techniques very lessas a good motivator and a good accommodator. LKY described himself as 'pragmatic' because he was prepared to look at the problem and say, all right, what is the best way to solve it that will produce the maximum happiness and well-being for the maximum number of people. Being focused in economic prosperity and pragmatic, there may be lack of hearing other and seeing other problem as own.

Charismatic nature is basis of affiliated leadership style. LKY has great charisma in his leadership model which is proved to be essential to have greater influence among followers, and at the same time to bring changes in a country. His communication skills were assertive yet powerful enough to bring people together. As Singapore was going through a tough period during the $1960 \mathrm{~s}$, his charismatic traits were pivotal in bringing unity among the people of Singapore as well as the leaders of other countries. People trusted him and the strict policies brought by him as Singaporeans believed it was for the betterment of the country.

One of the most enduring legacies was LKY's ability to select and work with a team of equally dedicated men all of whom shared one common characteristic. They loved Singapore and would put the nation interest above theirs. That more than anything drove the team to put aside differences for a common good. LKY and his team were obsessed with building a nation but they were never possessed by it. They never became personal or arrogant. Their obsession pushed them forward but they were not possessed by their egos.

This kind of leaders is masters of building a sense of belonging. The affiliated style's generally makes positive roleon economy, but leaders should employ it particularly when trying to build team harmony; increase morale; improve communication or repair broken 
trust. Goleman advocated that despite its benefits, the affiliated style should not be used alone.That its exclusive focus on praise can allow poor performance to go uncorrected, employees may perceive that mediocrity is tolerated.

\section{Democratic Style of Leadership}

The democratic leadership style focuses on collaboration. Leaders using this leadership style actively seek input from their teams, and they rely more on listening than directing. LKY uses discipline and democracy as co-exist leadership style for successful implementation of economic vision. Generally, people want their voices heard, their ideas lifted up, to be part of the solution, not in blind allegiance to any leader, but to what the country wants to achieve and how they are going to go about it. This style is best used when we need to get our team on board with an idea or build consensus.

LKY took regularly to the radio to explain to Singaporeans. In the simplest language, what the new country faced, what their government's policies would therefore be, what it would do and what its citizens needed to doinform about a situation. It's best to ask for input from team members who are motivated, knowledgeable and capable. LKY made involve team in problem solving and decision making, and teach them the skills they need to do this. He had mastered active listening and facilitation skills. This helped him to formulate pragmatic economic policies. LKY proposed a social contract that laid out for public understanding and consent the hard road ahead. LKY assured all to work hard and save. LKY said to his constituents too. As powerful visionary government, citizens facilities had been assured that there would educate their children and govern honestly and it would recruit the best talent, pay high wages.

In Lee's view, 'Democratic procedures have no intrinsic value. What matters is good government.' According him, the government's primary duty is to create a 'stable and orderly society' where 'people are well cared for, their food, housing, employment, health'. 'Democracy is one way of getting the job done, but if non-electoral procedures are more conducive to the attainment of valued ends, then I'm against democracy. Nothing is morally at stake in the choice of procedures.' LKY used both method for ensuring economic wellbeing of people and country.

The democratic leader asks employees to participate in the decision making process but maintain the final decision. By letting the workers themselves have a say in decisions that affect their goals and how they do their work, the democratic leader drives up flexibility and responsibility (Goleman, 2000). LKY took decision in collaboration with high officials. Listening to employees' concerns, the democratic leader learns what to do to keep morale high and because they have a say in setting their goals and the standards for evaluating success, people operating in democratic system tend to be very realistic about what can and cannot be accomplished (Goleman, 2000).

LKY's leadership style is indeed participative, 'sharing decision making with group members and working with them side by side.' In this case, LKY's group included his cabinet and party members, the experts he consulted with, the people of Singapore and many 
others. As Prime Minister it is important to consider other people's opinions but often he has the power of making the final decision. This is called consultative leadership. A consensus leader will aim to have all members agree on an issue although in LKY's case, it is virtually impossible as there are so many people involved when making decisions on behalf of the nation. A democratic leader is one who takes a vote on an issue to decide the outcome. The best example of that in LKY's case is holding a referendum.

\section{Pacesetting Style of Leadership}

The pacesetting leader sets both high standards for themselves and those they are leading. One of the key attributes of this style is the 'lead by example' approach. Pacesetting leaders are also quick to identify individuals that are not keeping pace with their expectations. Poor performers are asked to rise to the occasion, and if they do not, they are quickly replaced. LKY was such a leader who showed path going him in front. Singapore had nothing except uneducated labor force. LKY made path and walked for better economic performance. The phrase of pacesetting gives important meaning: 'Do as I do, now.' That's because this style is one that involves a drive to achieve initiatives, and a drive to achieve results.

LKY set meritocracy and followed strongly. Without talent manpower, there wouldn't be possible to run developing economy to prosperous. Pacesetting leadership style is that where they are able to quickly achieve results, there would be outstanding performance in terms of accomplishing tasks as well as the quality of the work itself. LKY wanted more works for betterment of life. The most effective way to use the pacesetting style of LKY was due to in need of quick results from a group that is already highly motivated and competent. This means the motivation that's driving the leader must also exist among the followers.

The style is also effective when group members are highly competent in the task they are going to complete. Whether this comes from aptitude or experience, the group members are going to be asked to work quickly. Very low level of economy and huge unemploymentinspired Lee for urgent need of economic advancement. LKY adopted this leadership style for making quick and decisive moves. Goleman, in his theory of emotional intelligence, has illustrated the pacesetting style of leadership. Pacesetting leadership style is deployed when a team is highly motivated and competent. This team may find the high standards challenging and exciting, needing little direction or coordination while trying to accomplish its goals. However, a constant enhancement in objectives previously met may leave the team drained and unmotivated from continuing further.

A leader with a pacesetting leadership style illustrates high standards for performance. Leaders who possess such a leadership style seek coordination with the members when they believe there is an impact on an immediate task. A leader should adapt a pacesetting style of leadership when one would develop his or her professional or technical expertise. The leader can lead by example, and be a model of behavior one wishes to perceive. When a team member needs backing, a leader needs to instruct them on how one should handle the situation, and all possible obstacles must be foreseen, as the ways of overcoming them. It needs to be explained to the team member exactly what they need to do in those circumstances. 
The pacesetting leadership style focuses on performance and meeting goals. Leaders using this leadership style expect excellence from their teams, and often the leader will jump in him /her to make sure that goals are met. The pacesetting leadership style is best used when you need to get high quality results from a motivated team, quickly. According to Goleman (2000), with pacesetting style 'the leader sets extremely high performance standards and exemplifies himself. He is obsessive about doing things better and faster, and he asks the same of everyone around him. He quickly pinpoints poor performance and demands more from them.'

Leading the Singapore government for three decades, LKY was credited with turning Singapore from an underdeveloped to one of the richest countries in the world in one generation. A champion of meritocracy, lee ensured that Singapore's civil service attracts and retains superior talent by paying them higher than the private sector. LKY also invested heavily in education to create a highly-skilled workforce. In addition to that, a national culture that anyone can rise up the social ranks through hard work and LKY's own heavy-handed style of management made conditions ripe for pacesetting leadership.

LKYwas a dreamer and an achiever. LKY was certainly a skillful leader who was monumental in transforming a small-poor island city into a global economic hub commonly known for his 'Economic Miracles'. His attributes and traits were phenomenal. His ability to give proper attention to even the smallest details was praised by many world leaders. It isn't by chance that Singapore is the cleanest city in the world along with the most disciplined citizens. His strict regulations and assertive approach have been paid off effectively.

\section{Coaching Style of Leadership}

A coaching style of leadership is characterized by partnership and collaboration. When leaders behave like coach, then hierarchy, command and control give way to collaboration and creativity. Blame gives way to feedback and learning, and external motivators are replaced by self-motivation.

To bring out the necessary consensus for economic growth, there has tomaintain benefits and incentivesamong stakeholders which is to be aligned over a broad range of interests of citizens. In fact, there is no single road that leaders must follow; rather, leaders decide and implement policies within specific historical, cultural, and economic contexts. Coaching is the one leadership style by which many voices might have got unified. It is process of a transforming culture and in which leadership styles changes from directing to coaching. Instead of one brain driving the show, coaching leadership connects the minds (and hearts!) of the whole team, and trusts them to deliver outstanding performance.

LKY as an authentic leader genuinely desires to serve others through his leadership. His passion and commitment has been for the continued economic growth of Singapore to be a place where future generations will live, work and thrive. LKY achieved that with humility and authenticity, and with courage and confidence in Singapore as a nation, to achieve great things. A 'Coaching Style Leadership' delivers huge benefits to individuals and nation. 
Leaders who adopt a coaching style increase self-responsibility and self-belief in their people by giving choice wherever possible, and providing a good balance of support and challenge.

The coaching style of leadership connects people's personal goals with the nation's goals. A leader using this style is empathic and encouraging, and focuses on developing others for future success as Lee did to develop his successor. Singapore was a very diverse country with people from different races facing several types of problems including unemployment, poor life standard and lack of housing. The nation was in crisis but Lee had something better in his mind. LKY had a vision of making Singapore self-dependent and self-reliant. He wanted to create a sustainable country for the future. There were many challenges that came along the way but like all great leaders, he overcame those problems. LKY was a flexible and dynamic leader who played vital roles in maintaining peace, harmony, and unity even in hard times through coaching leadership styles.

The 'Coaching Style of leadership' should be used whenever you have a team member who needs help building long-term skills. Coaching leaders, according to Goleman (2000), 'help employees identify their unique strengths and weaknesses and tie them to their personal and career aspirations'. Goleman further posits that coaching leaders excel at delegating; they give employees challenging assignments, even if that means the task won't be accomplished quickly. In other words, these leaders are willing to put up with short-term failure if it furthers long term learning. Goleman (2000) has admitted that there is a paradox in coaching's positive effect on business performance because coaching focuses primarily on personnel development, not on immediate work related tasks.

LKY over the years has shown a tremendous emotional intelligence throughout his years as the prime minister of Singapore and after the tenure as well. In his 31 years of being a prime minister, he has seen it all from a country with no resources and being dependent to other countries for the basic necessities, to a country that has now one of the highest GDP, PPP and per capita income and the lowest crime rate in the world. LKY was able to withstand all the failures and criticism and focus on the main goal of making Singapore - a city of the future.

The basis of the 'Coaching Style of Leadership' is the dynamic interaction between the leader and the employee. This gives rise to valuable insights and the achieved results are discussed and analyzed. This is done by means of providing and receiving feedback, asking questions and conducting motivating conversations. A good coach encourages the learning process of the coached person and promotes the responsibility and independence of the employees. As stated above, the goal of coaching is to develop qualities and competences.

There are many interest groups in developing the nation. Good communicative skills are invaluable in the coaching syle of leadership. Objectives and expectations must be discussed, so everyone is clear on role. In this way, bureaucrats or the employees are encouraged to work in a responsible and creative manner as adopted by LKY for building nation. 


\section{Discussion}

Seldom will a leader employ only one leadership style to be able to achieve any management or leadership goal. There is no 'one best way' of leadership and the most successful leaders adjust their leadership style to the maturity of the individual or the group and also to the task which is to be performed. Goleman (2000) concluded that leaders who have mastered four or more-especially the authoritative, democratic, affiliated, and coaching styles have the very best climate and business performance. The most effective leader uses a collection of distinct styles-each in the right measure at just the right time. Such flexibility is tough to put in action, but it pays off in performance.

Goleman (2000) argued that in turbulent times effective leaders need to: demand immediate compliance with coercive leadership style; mobilize people toward a vision with an authoritative leadership style; create harmony and build emotions with an affiliative leadership style; forge consensus through participation with a democratic leadership style; set high standards for performance with a pacesetting style; and develop people for the future with the coaching style. The Authoritative, coaching, Affiliative, and democratic styles promote harmony and positive outcomes while coercive and pacesetting may create tension, and should only be used in specific situations. There is no a single style be used all of the time at all places. Instead, the given six styles should be used interchangeably that depend on the specific needs of the situation and the people that you're dealing with.

LKY has dynamic leadership style for meeting the prosperity of a country and mixes all possible leadership style as a pragmatic way to get stated economic results of a poor country. There were enough challenges after independence of Singapore. Low economic growth, high rate of unemployment, racial strife and ideological differences have been prevalent in the country. In such a situation, envisioning for best economic policies for rapid growth was very far and foremost difficult work.

Coercive style of leadership was used for shaping citizen's loyalty towards continuous inclination in productive work. Singapore was in turbulent situation. Effective leaders need to demand immediate compliance with coercive leadership style as did by LKY in moderate way. The fluid situation of a country must have been directed toward economic advancement of a country with a lot of united effort. LKYwasable to choose the best style according to time and situation with a greater vision ofmaking Singapore big. It is really great to use leadership style in accordance with understanding reading others and the situation of the country.

While Singapore was independent, there were only uneducated labor forces without enough natural resources and low economic condition. Without destination of economic vision, there wasn't any economic path to move to prosperity. There was a need of leadership to mobilize people toward a vision. LKY used heavily authoritative leadership style in building Singaporean economy to prosperity. His authoritative style was needed to run

low economic condition to higher level of economic performance. Therefore, high level of authoritative style has resulted high economic growth in Singapore.

LKY created harmony and build emotions with an affiliative leadership style in a 
moderate way to have better economic performance of a country by devoting all efforts to make Singapore prosperous. Without this skills, there might have generated many racial, social and economic problems within the different communities. Winning by heart is a great art and sustainable techniques of political leadership for implementing their vision.

LKY had a great sense of legislation and also conscious on forging consensus among stakeholders and ideologues for making the nation better. Election had been held, different forum was developed to enhance voice of people. To enhance economic performance, forging consensus through participation with a democratic leadership style was vital. LKY used this style moderately.

LKY had built confident environment to all internal and external investors that help to increase employment opportunities and enhance international trade. Flexible labor policy and tax policy were adopted. Clear working procedures and process were very important to implement economic policies. LKY didn't compromise on quality products and performance with high standard services by adapting a pacesetting style of leadership. LKY mastered other language skills to guide and inspire all citizens to learn. LKY could instruct instantly if needed on how one should handle the situation, and all possible obstacles must be foreseen, as the ways of overcoming them.

Very important leadership characteristics of LKY's were to succeed followers to get motivated and making those responsible leaders in the days to come. To inspire immediate follower is to enhance their personal development to apply all leadership qualities. LKYdeveloped people for the future with the coaching style. While doing this unity, harmony was developed to walk along with greater economic vision of a country. 'Leadership Succession Planning' was main feature of LKY who headed 31 years active role and 25 years auxiliary role of political leadership to make the county economically healthier and prosperous. LKY was a leader who led by example and be a model of behavior one wishes to perceive.

\section{Conclusion}

Leaders play a critical role in collective action, shaping movements in numerous ways. They define goals and advance strategies. They mobilize followers, galvanize indigenous organizations, and forge coalitions. They influence responses to external repression, and their action, rhetoric, and style affect conflict outcomes. No doubt, each style works best in different situations, resonating differently with team, and producing different results. Anyone can learn how to use these leadership styles. But it's important to remember that these styles are meant to be used interchangeably, depending on the needs of situation and circumstances to attain more effectiveness of economic performance. The effectiveness of LKY's leadership style with the aid of the above model seems to be outstanding in economic prosperity perspectives.

LKY is one great example of such a leader whose leadership style, traits, roles, and influence was viable to change the face of Singapore immensely within just few decades. It is 
believe that there is a lot to learn from an inspiring personality like LKY style of leadership has changed the layout of Singapore in just a single generation of leadership despite many obstacles that came along his way.It's important to note that LKY was very near to locate Goleman's six leadership styles where leadership practices of LKY have almost contributed Goleman to theories. Applying Goleman's six leadership styles prove to be very important for effective political leadership create positive economic performance. A good leader is expected to have components of all six styles and understand when and how to use them to get higher results of stated economic vision of nation.

Leading the Singapore government for three decades, LKY was credited with turning Singapore from an underdeveloped to one of the richest countries in the world in one generation. A champion of meritocracy, lee ensured that Singapore's civil service attracts and retains superior talent by paying them higher than the private sector. LKY also invested heavily in education to create a highly skilled workforce. In addition to that, a national culture that anyone can rise up the social ranks through hard work and LKY's application of all Goleman's leadership style made conditions ripe for both peace and prosperity in a small country, Singapore.

\section{References}

Barker, B. (2001). Do leaders matter?Educational Review, 53(1), 65-76. https://doi. org/10.1080/00131910120033664

Bass, B. M. (1985). Leadership and performance beyond expectation. New York, NY: Free Press.

Bass, B. M. (1990). From transactional to transformational leadership: Learning to share the vision. Organizational Dynamics, 18(3), 19-31.

Bertrand, M. \& Schoar, A. (2003). Managing with style: The effect of managers on firm policies.Quarterly Journal of Economics, 118, 1169-1208.

Besley, T., Montalvo ,J. \& Reynal-Querol, M. (2011). Do educated leaders matter? The Economic Journal, 121, 205-227.

Bikienga, S. (2015). Leadership and economic growth: A text analytics approach leadership traits. Working Paper, 1-34.

Blondel, J. (1987). Political leadership - towards a general analysis. London: SAGE Publications Ltd.

Brady, D. \& Spence, M. (2010). Leadership and politics: A perspective from the growth commission, Oxford Review of Economic Policy, Vol. 25, No. 2, pp. 205-218.

Ekene, C. \& Ugwunwanyi, A. (2016). Leadership and economic development in a developing economy: Acriticallook at the Nigeria'sexperience. International Journal of Business and Management Review, 4(6), 105-114. 
72 | The Economic Journal of Nepal (Issue No. 151)

Fiedler, F. E. \& Garcia, J. E. (1987). New approaches to effective leadership. New York, NY: John Wiley.

Goleman, D. (2000). Leadership that gets results. Harvard Business Review, 79(2), 78-87.

Hermalin, B. E. (2007) .Leading for the long term. Journal of Economic Behavior \& Organization, 62 (1): 1-19.

Jones, B. \& Olken, B. (2005). Do leaders matter? National leadership and growth since World War - II. Quarterly Journal of Economics 120(3), 835-864.

Kebonang, Z. \& Kebonang, S. (2013). Does leadership matter to development: The case of Botswana, Zimbabwe, Nigeria and Indonesia. Journal of Politics and Good Governance, 4(4), 1-24.

Kendra, C. (2012) Leadership theories: The 8 major leadership theories. Retrieved from http://psychology.about.com/od/leadership/p/leadtheories.htm> [26/3/2012]

Lee, K. (2000). From third world to first: The Singapore story: 1965-2000. Singapore: Singapore Press Holdings.

Northouse, P. G. (2013). Leadership: Theory and practices $\left(6^{\text {th }} \mathrm{e}^{\mathrm{n}}\right.$.). Thousand Oaks, CA: Sagepublication.

Richardson, G. (1994). Singapore-2003: Aspiring to the first world, London: The Economist Intelligence Unit.

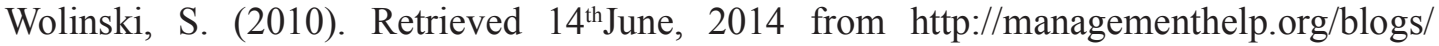
leadership /201 0/04/2 I/leadership theories/.

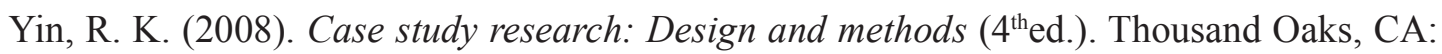
Sage.

Zhang, H.(2015). National leaders and economic growth: What characteristics matter?https:// doi.org/10.1111/0022-1082. 